\title{
NON-LINEARITY OF AUDIT PRICES AND REPUTATION IN DEVELOPING COUNTRIES: SHIFT TO OR FROM?
}

\author{
Svitlana SHULHA ${ }^{1}$ \\ National Academy of Statistics, Accounting and Auditing, Ukraine \\ laroslav PETRAKOV ${ }^{2}$ \\ Chernihiv National University of Technology, Ukraine
}

\begin{abstract}
The purpose of the paper is to analyse the origins of audit prices non-linearity in developing countries. We assume risk- and industry-sensitiveness of audit firms there due to the low institutional capacity, weak market forces development and questionable both auditors and clients ethical behaviour affecting market sustainability and implying additional challenges on stakeholder confidence. Methodology. We combine economic geography approach and reputation-averse phenomenon to explain endogenous volatility of average audit prices in Ukraine for the period of 2008-2015. Analysis of recent publications partially explains audit pricing non-linearity determinants that have both qualitative (brand and specialization) and quantitative (risks, manipulations, bribery) nature in developing countries. First, we qualify determinants of audit fees by inherent origin (endogenous, exogenous), stakeholder side (demand, supply), and market structure (concentrated, fragmented). Second, we summarize reputation challenges of audit business in developing countries. Third, we run empirical analysis of average prices in Ukraine for the period of 2008-2015 based on annual Chamber of Auditors of Ukraine reports data. Practical implications. Audit pricing models in developed countries are mainly exogenous and based on the auditor's risk assessment. Vulnerability of markets and clients' unethical behaviour makes audit pricing models more endogenous in developing countries. Value/originality. This is the first paper providing a better understanding of audit prices declination in Ukraine as a consequence of dysfunctional audit firms' behaviour, institutional and market fragility, inherent to developing countries.
\end{abstract}

Key words: audit pricing, risks, developing countries, reputation, fee premium.

JEL Classification: M41, M42

\section{Introduction}

Audit fees, traditionally, are among regularly discussed issues between theregulators, businesses and professional society. Audit pricing remains very important also for researchers in general (Barkess \& Simnett, 1994, Beatty, 1989) discussions on determinants (Ward, Elder \& Kattelus, 1994) and basic models (Giroux \& McLelland, 2008, Pong \& Whittington, 1994, Raluca, 2011). Traditionally, main arguments in pricing debates favour such factors as size (Carson \& Fargher, 2007, Sundgren \& Tobias Svanström, 2013), industry (Ballas \& Fafaliou, 2008), and risk (Bell, Dooger \& Solomon, 2008, Jubb, Houghton \& Butterworth, 1996).

Our recent findings in this area suggest that pricing models shift from endogenous to exogenous factors, what can be explained by growing pressure of main stakeholders - clients and regulators through their control of the ethical, quality, social and public governance issues (Shulha, 2016). They are supported by other findings for developed countries (Francis \& Wang, 2005, Willenborg, 1999).

Instead, lower institutional capacity, weaker market forces development and questionable behavioural issues in developing countries pose additional challenges for local audit markets (Petrakov, 2013, Shulha \& Petrakov, 2015, Schatzberg, 1990).

Unquestionably, quality of audit services should be regarded as a keystone of any report (Sundgren \& Svanström, 2013) but such statement sounds uneven for developing countries (Korotkiy \& Petrakov, 2009). Audit fee premiums are traditionally correlated with reputation (Carson \& Fargher, 2007, Chaney \& Philipich 2002, Kreps \& Wilson, 1982, Moizer, 1997, Francis, Reichelt \& Wang, 2005, Shapiro, 1983) and auditor independence (Barkess \& Simnett, 1994,) which in developing countries are under pressure due to corruption, unethical behaviour and limited client's payability. Although there are some evidences

\footnotetext{
Corresponding author:

${ }^{1}$ Department of Audit, National Academy of Statistics, Accounting and Auditing.

E-mail:stshylga@ukr.net

${ }^{2}$ Department of Accounting, Taxation and Auditing, Chernihiv National University of Technology.

E-mail: yacherny@ukr.net
} 
on an impact of perceptions (Figueroa, 2013) and dysfunctional behaviour (Immordino \& Pagano, 2012, Yuen, Law, Lu \& Guan, 2013) on auditing pricing.

We think that audit pricing non-linearity in developing countries origins from weaker markets' sustainability and stakeholders' distrust. In case of Ukraine this hypothesis can be analysed through average audit prices during the last decade.

In order to check this idea we will combine economic geography approach (El Ghoul, Guedhami, Ni, Pittman \& Saadi, 2013, El Ghoul, Guedhami \& Pittman, 2014) and reputation-averse phenomenon (Choi, Kim, Liu \& Simunic 2008), to explain endogenous volatility of average audit prices in Ukraine during 2008-2015.

First, we qualify determinants of audit fees by inherent origin (endogenous, exogenous), stakeholder side (demand, supply), and market structure (concentrated, fragmented). Second, we summarize reputation challenges in developing countries. Third, we run empirical analysis of average prices in Ukraine during 2008-2015 based on Chamber of Auditors of Ukraine annual reports.

\section{Determinants of audit pricing in developing countries}

Analysis of recent publications partially explains the determinants of audit prices non-linearity arising both from qualitative (brand and specialization) and quantitative (risks, manipulations, bribery) issues in developing countries. Client's payability (to cover highquality audit) and auditor's reputation (as independent and experienced entity) are particularly important for market stability: financially constrained clients may pose additional pressure on an auditor to limit the number of substantive procedures (affecting sufficiency of gathered information) while an auditor with "low balling" reputation may potentially curb financial statements' signals to investors and other stakeholders.
Non-linearity of audit fees in developing countries can be explained with asymmetric distribution of competent auditors within active entities - they are often attracted with Big4 or second-tier companies that are present at contestable markets widening the price gap between low-balling and premium-consistent contracts. As unhealthy competition strives market participants, general economic conditions play an important role in sustaining its capacity to generate high-quality services. In stagnant economy depressed market obviously narrows an auditor's ability to use the scale effect in pricing. Thus, by the criteria of inherent origin fee determinants are shifted from endogenous to exogenous (see table 1). The same we can state concerning prevailing demand-side as seen in market side analysis of the determinants.

\section{Reputation challenges in developing countries}

Challenges for audit entities and engagements in ethical area in developing countries originate from several sources:

1) low quality of basic accountancy and auditing education of team assistants and staff as a consequence of weak ties between auditors and universities;

2) "brain-drain" of young professionals, trained within Big4 in developing countries, to advanced economies; thus leaving "homeland" with "second-best" supply-side options;

3) slow and lagging transition to the International Audit Standards and Code of Ethics, imposing institutional laggings and phenomenon of dysfunctional behaviour of auditors.

Besides traditional challenges there could be mentioned force-majeure issues such as international conflicts, unfear sectorial competition (aggressive M\&As), political crises (affecting FDI inflows and free trade conditions). All above-mentioned factors affect audit market in long-term perspective and its lagged

Table 1

Determinants of audit pricing in developing countries

\begin{tabular}{|c|c|c|c|c|c|c|c|c|c|c|c|c|c|c|}
\hline & Type & 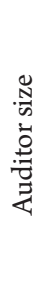 & 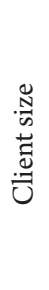 & 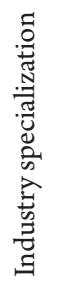 & 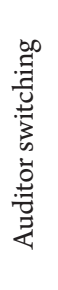 & 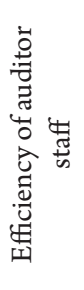 & 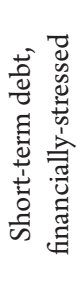 & 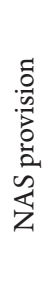 & 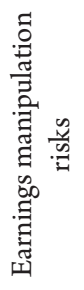 & 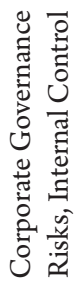 & 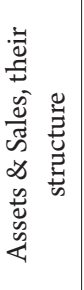 & 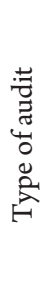 & 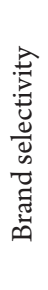 & 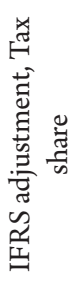 \\
\hline \multirow{2}{*}{ Inherent origin } & Endogenous & + & & & & + & & + & & & & + & & \\
\hline & Exogenous & & + & + & + & & + & & + & + & + & & + & + \\
\hline \multirow{2}{*}{ Market structure } & Concentrated & + & + & & & + & & & & & + & & + & \\
\hline & Fragmented & & & + & + & & + & + & $\mathrm{n} / \mathrm{a}$ & $\mathrm{n} / \mathrm{a}$ & & + & & $\mathrm{n} / \mathrm{a}$ \\
\hline \multirow{2}{*}{ Market side } & Demand & & + & & + & & + & + & + & + & + & + & + & + \\
\hline & Supply & + & & + & & + & & & & & & & & \\
\hline
\end{tabular}

Notes: ${ }^{*}$ - not applicable.

Source: the authors' compilations. 
recovery. Thus, regulatory position and impact can either support professionals or create additional barriers to auditors.

Empirical analysis of average prices in Ukraine during 2008-2015 based on Chamber of Auditors of Ukraine annual reports (see Pic. 1 and Pic. 2) provides us with some important data:

1) average fee per contract in UAH demonstrates strong increase within the time framework from 15,27 thousands hryvnias to 49,4 thousands hryvnias for one contract. At the same time total amount of deals declined almost by the half. We could suggest that such non-linear dynamics may result from industry concentration and increase of unit costs or complexity of a subject company. Though average fee per contract in USD remained constant what means prices were inelastic (not market determinants driven);

2) USD-based fees per contract peak in 2013 and further decline by $30 \%$ in 2015 demonstrated negative market trend for industry marginalization under challenging country conditions and mass bankruptcies in corporate and banking sectors during 2014-15 making it less attractive to foreign industry professionals and investors.

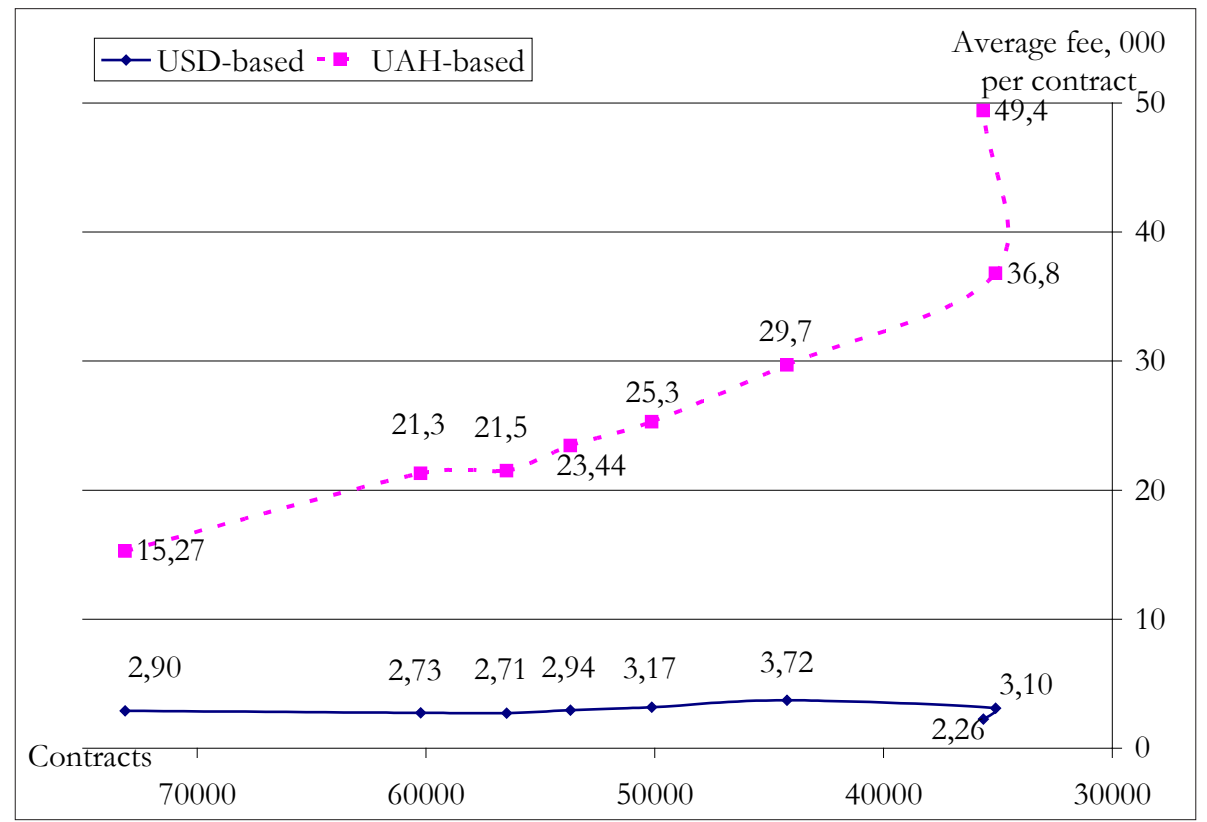

Pic. 1. Average audit fees (UAH, USD based on current prices) in Ukraine, 2008-2015

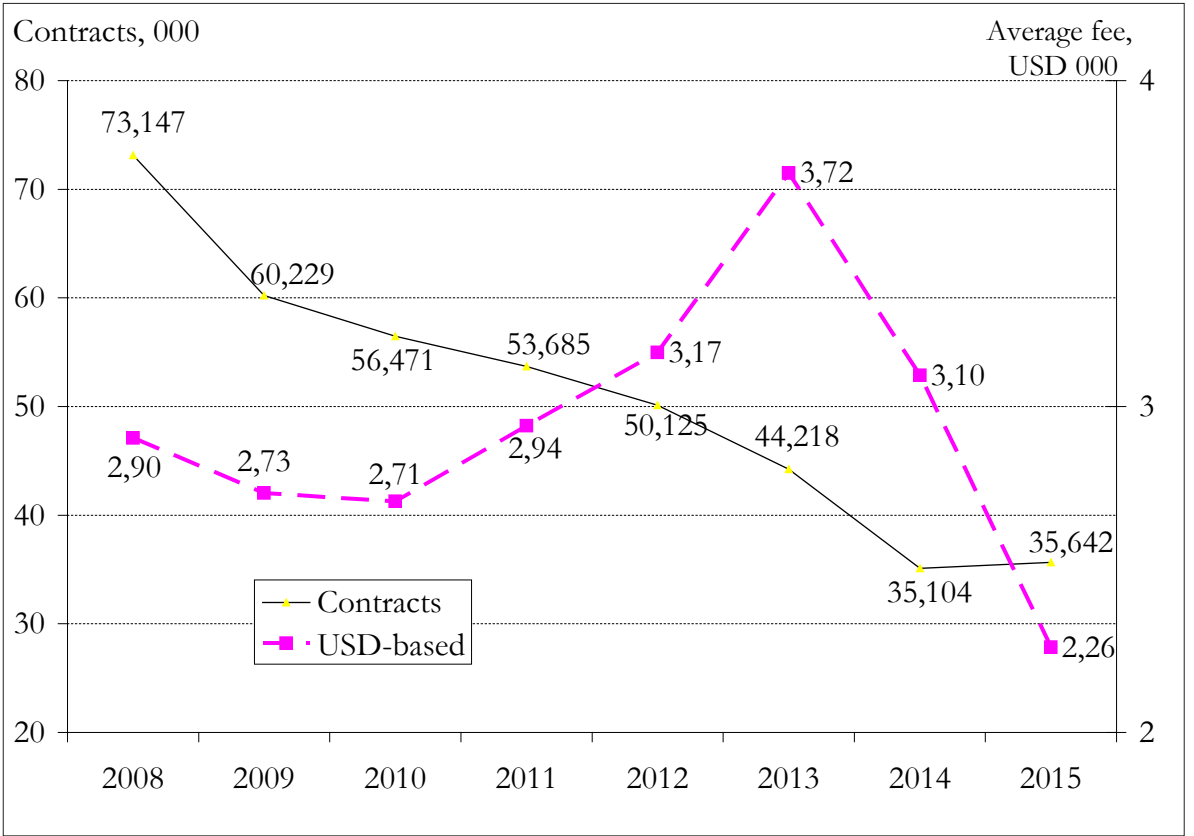

Pic. 2. Dynamics of Ukrainian audit market average fee 


\section{Conclusions}

Practical implications. Audit pricing models in developed countries are mainly exogenous and based on an auditor's risk assessment. Vulnerability of markets and clients' unethical behaviour makes audit pricing models more endogenous in developing countries. Value/originality. This is the first paper providing a better understanding of audit prices declination in Ukraine as a consequence of dysfunctional audit firms' behaviour, institutional and market fragility, inherent to developing countries.

\section{References}

Abdulmalik, O.S. and A. Che Ahmad (2016). Boardroom diversity and audit fees: diectory ethnicity, independent and nationality, Audit financiar, 14(4):413-423.

Ballas, Apostolos A., and Irene Fafaliou (2008). Market Shares and Concentration in the EU Auditing Industry: the Effects of Andersen's Demise, International Advances in Economic Research, 14(4):485-497.

Barkess, Lynn \& Roger Simnett (1994). The Provision of Other Services by Auditors: Independence and Pricing, Journal of Accounting and Business Research, 24(94): 99-108. Retrieved from: http://www.tandfonline.com/ doi/abs/10.1080/ᄀ00014788.1994.9729469

Beatty, Randolph P. (1989). Auditor Reputation and the Pricing of Initial Public Offerings, The Accounting Review, 64(4): 693-709.

Bell, T.B., Dooger, R., \& Solomon, I. (2008). Audit Labour Usage and Fees under Business risk Auditing. Journal of accounting research, 16 (4): 729-760

Butterworth, S., and K.A. Houghton (1995). Auditor Switching: The Pricing of Audit Services, Journal of Business Finance and Accounting, 22, (3): 323-344.

Carson, Elizabeth and Neil Fargher (2007). Note on audit fee premiums to client size and industry specialization, Accounting and Finance, 47(3): 423-446.

Chamber of Auditors of Ukraine. - Annual reports to the Cabinet of Ministers of Ukraine (2008-2015). Retrieved from: http://www.apu.com.ua/zvit-do-kmu

Chaney, Paul K., and Kirk L. Philipich (2002). Shredded Reputation: The Cost of Audit Failure, Journal of Accounting Research, 40(4): 1221-1245.

Choi, Jong-Hag, Jeong-Bon Kim, Xiaohong Liu, and Dan A. Simunic (2008). Audit Pricing, Legal Liability Regimes, and Big 4 Premiums: Theory and Cross-country Evidence, Contemporary Accounting Research, 25(1): 55-99.

Donnelly, D.P., D.O. Bryan, and J.J. Quirin (2003). Auditor acceptance of dysfunctional audit behaviour: An explanatory model using personal characteristics, Behavioural Research in Accounting, 15:87-110.

Figueroa, Carmen Rios (2013). The Effect Of Cultural Knowledge In The Perception Of Auditors: Internal Controls And Fraud, Revista Global de Negocios, 6(2):15-32.

Francis J., K. Reichelt, and D. Wang (2005). The pricing of national and city-specific reputation for industry expertise in the U.S. audit market, The Accounting Review, 80(1): 113-136.

Giroux, Gary, and Andrew McLelland (2008). A Municipal Audit Fee Model Using Structural Equation Modeling, The Journal of Applied Business Research, 24(3): 135-146. - Retrieved from: http://harbert.auburn.edu/ mclelaj/research_files/JABR08.pdf

El Ghoul, Sadok, Omrane Guedhami, Yang Ni, Jeffrey Pittman, Samir Saadi (2013). Does information asymmetry matter to equity pricing? Evidence from firms' geographic location, Contemporary Accounting Research, 30(1):140-181.

El Ghoul, S., O. Guedhami, and J. Pittman (2014). Cross-country evidence on the importance of Big Four auditors to equity pricing: The mediating role oflegal institutions. Retrieved from: http://dx.doi.org/10.2139/ssrn.1567524 Hay, David C., Robert W. Knechel, and Norman Wong (2006). Audit Fees: A Meta-analysis of the Effect of Supply and Demand Attributes, Contemporary Accounting Research, 23(1):141-91.

Immordino, Giovanni, and Marco Pagano (2012). Corporate Fraud, Governance and Auditing, Review of Corporate Finance Studies, 1(1): 109-133

Jubb, C.A., K.A. Houghton, \& S. Butterworth (1996). Audit fees determinants; the plural nature of risks, Managerial Auditing Journal, 11(3): 25-40.

Korotkiy, V., and I. Petrakov (2009). Methodlogical approaches for audit quality control in Ukraine, Journal of Chernihiv State Techological University, 38: 189-198.

Kreps, D., and R. Wilson (1982). Reputation and imperfect information. Journal of Economic Theory, 27: $253-279$. Lyon, John D., Michael W. Maher (2005). The Importance of Business Risk in Setting Audit Fees: Evidence from Cases of Client Misconduct, Journal of Accounting Research, 43(1): 133-151.

Moizer, P. (1997). Auditor Reputation: the International Empirical Evidence, International Journal of Auditing, 1(1): 61-74.

Nehme, Rabih, Abdullah Al Mutawa, and Mohammad Jizi (2016). Dysfunctional behaviour of external auditors the collision of time budget and time deadline evidence from a developing country, The Journal of Developing Areas, 50(1): 373-388. 
Petrakov, I. (2013). Theory of contestable markets and audit in Ukraine: an identification problem, Journal of Chernihiv State Techological University, 68: 248-258.

Pong, Christopher K.M. and Geoffrey Whittington (1994). The determinants of audit fees: Some empirical models, Journal of Business Finance \& Accounting, 21(8): 1071-1095.

Raluca, I. (2011). Audit Fee Econometrical Models: An Overview of the Auditing Research Literature, Annales Universitatis Apulensis Series Oeconomica, 13(2):378-386.

Schatzberg, J. W. (1990). A Laboratory Market Investigation of Low Balling in Audit Pricing, The Accounting Review, 65(2): 337-362.

Shapiro, C. (1983). Premium for high quality products as return to reputation, Quarterly Journal of Economics, 98: 659-680.

Shulha, S. and I. Petrakov (2015). Integrated Reporting as Competitive Advantage for Ukrainian Companies: Determinants vs. Biases, Business-inform, 10: 26-30.

Shulha, Svitlana (2016) Models and factors of audit and NAS pricing: literature overview, Forthcoming in BusinessInform, 10.

Simunic, Dan A. (1980). The Pricing of Audit Services: Theory and Evidence, Journal of Accounting Research, 18(1): 161-190. Retrieved from: http://wlkc.gdqy.edu.cn/-res/skillsres/resources/2012/04/-05/18/38E1C260622E-4BE0-A260-C2B107218D65.pdf

Sundgren, Stefan, and Tobias Svanström (2013). Audit office size, audit quality and audit pricing: evidence from small and medium-sized enterprises, Accounting and Business Research, 43(1):31-55.

Wallace, W. A. (1989). Are audit fees sufficiently risk adjusted? Advances in Accounting 7 (Supplement): 3-37.

Ward, D. D., R. J. Elder, and S. C. Kattelus (1994). Further evidence on the determinants of municipal audit fees. The Accounting Review, 69 (2): 399-411.

Willenborg, M. (1999). Empirical analysis of the economic demand for auditing in the initial public offerings market. Journal of Accounting Research, 37 (1): 225-39.

Yuen, Desmond C.Y., Philip K.F. Law, Chan Lu, and Jie Qi Guan (2013). Dysfunctional auditing behaviour: empirical evidence on auditors' behaviour in Macau, International Journal of Accounting \& Information Management, 21(3): 209-226.

\section{Светлана ШУЛЬГА, Ярослав ПЕТРАКОВ}

\section{НЕЛИНЕЙНОСТЬ ЦЕН НА АУДИТ И РЕПУТАЦИИ В РАЗВИВАЮЩИХСЯ СТРАНАХ: ДВИЖЕНИЕ К ИЛИ ОТ?}

Аннотация. Целью работы является анализ источников нелинейности цен на аудиторские услуги в развивающихся странах. Мы предполагаем, что аудиторские фирмы чувствительны к рискам и отраслевой принадлежности (нелинейно) ввиду низкой институциональной способности, слабости рыночных сил и сомнительного поведения со стороны как аудиторов, так и клиентов. Это значительно ухудшает устойчивость рынков и порождает дополнительные вызовы для доверия их основных участников. Методика. Мы соединили экономическую географию с феноменом обратной репутации для объяснения эндогенной волатильности средних цен на аудиторские услуги в Украине в 2008-2015 годах. Анализ недавних публикаций частично поясняет детерминанты нелинейности ценообразования, возникающие под воздействием как качественных (бренд и специализация), так и количественных (риски, манипуляции, мошенничество) факторов в развивающихся странах. Во-первых, мы квалифицируем факторы, влияющие на аудиторский гонорар по критериям первичного происхождения (эндогенные, экзогенные), групп заинтересованных лиц (стороны спроса и предложения), структуры рынка (центрированный, фрагментированный). Во-вторых, мы обобщаем репутационные вызовы аудитов в развивающихся странах. В-третьих, мы проводим эмпирический анализ среднего размера гонорара аудиторов в Украине в 2008-2015 годах на основе ежегодных отчетов Аудиторской палаты Украины. Результаты. Практическое значение исследования заключается в том, что модели ценообразования в развитых странах преимущественно экзогенны и базируются на оценке рисков аудитором. Уязвимость рынков и неэтическое поведение клиентов в развивающихся странах делает модели ценообразования в аудите более эндогенными. Значение/оригинальность. Данная публикация впервые объясняет причину снижения средних цен сравнительных цен на аудиторские услуги в Украине как следствие дисфункционального поведения аудиторских фирм, а также институциональной и рыночной слабостей, присущих развивающимся странам. 